\title{
Money injection for public services
}

\author{
Where should we direct these precious extra resources?
}

\author{
Richard Murray chief executive
}

King's Fund, London, UK

On 11 March, Rishi Sunak, the chancellor of the exchequer, presented his first budget and promised an extra $£ 5$ bn $(€ 5.7 \mathrm{bn}$; $\$ 6.2 b n$ ) for public services to help them deal with covid-19. ${ }^{1}$

What is the $£ 5$ bn for? $£ 1.6$ bn is going to local authorities to support social care, social care staff, and the vulnerable. $£ 1.3 \mathrm{bn}$ is going to support quicker discharge from NHS hospitals, ${ }^{2}$ with the aim of freeing up 15000 beds and capacity for the expected surge in emergency admissions. The rest was not earmarked, but it is easy to see what many of the big ticket items are, at least for the NHS and social care. An unprecedented deal to buy up capacity in the private healthcare sector will come at a price (even though it is being bought at cost) but brings with it beds, equipment, and, most critically, staff. Additional tests, ventilators, and personal protective equipment (PPE) and creating new hospitals in conference centres across the UK are also priorities. Expansion of the work force, however hard that is, will of course push up the wage bill.

\section{Question of supply}

However, in all of these examples, the financial hit born by the Treasury will not be determined solely by the announcements in the Budget but by how much can actually be bought. The government would be happy to pay for more intensive care nurses, for example, but money is not the issue (to the government's credit)—it is supply.

The chancellor has made clear that the NHS will get "whatever it needs" to respond to the outbreak. This reverses the normal budgeting process. Instead of asking, "How much money have I got to spend?" the question becomes, "How many tests, nurses, and doctors (and how much personal protective equipment) are there to buy?" If the government can source extra supply, then the promised $£ 5$ bn will just be the beginning, and this has been made clear to the service.

The government's plans do not lack ambition or a willingness to spend, and most NHS leaders are supportive. ${ }^{4}$ Yet in some areas this simply underlines the core problem: it is difficult to buy yourself out of the underlying capacity constraints, especially as other countries are competing for the same supplies.

What else can be done? Telling NHS bodies to spend, spend, spend is easy. NHS trusts are part of the public sector, so this is no more than moving money from one of the government's bank accounts into another. However, this is less straightforward for general practice and for social care, which are not public sector bodies. Ensuring that all providers in the health and care system-including small social care providers and voluntary sector organisations-get a timely share of the chancellor's extra cash is vital.

\section{Lateral thinking}

There is also a case for some lateral thinking. Distressed NHS staff should not be faced with supermarket shelves that have been emptied while they work. Vital shopping could be done for them, through direct deliveries, reserved online shopping, or by volunteers. ${ }^{5}$ Some such schemes are already available, but a more coordinated effort could scale this up nationally and ensure everyone (including social care staff) can benefit.

As we move through the crisis, leaders should stay close to their staff to understand what other practical things can be done to help, such as use of taxis to get staff to work when public transport is inadequate or overcrowded. Alongside this, proper funding for staff health and wellbeing-particularly mental health-is essential now and should endure beyond the crisis. Lastly, as we enter the most difficult weeks of the epidemic, there is a strong case for spending judiciously on capturing the learning and experience currently being gained at such cost. Whether in supporting new ways of working, the rapid uptake of digital technology, or the experience of leading compassionately in a crisis there is much that could provide a lasting benefit both to the NHS and to people's health.

Competing interests: We have read and understood BMJ policy on declaration of interests and have none to declare.

Provenance and peer review: Commissioned; not externally peer reviewed.

Anandaciva S. What does the 2020 spring Budget mean for health and care? King's Fund, 2020. www.kingsfund.org.uk/blog/2020/03/spring-budget-mean-health-and-care

2 Department of Health and Social Care. Ministry of Housing, Communities and Local Government. £2.9 billion funding to strengthen care for the vulnerable, 19 Mar 2020. www. gov.uk/government/news/2-9-billion-funding-to-strengthen-care-for-the-vulnerable

3 Stevens S, Pritchard A. Next steps on NHS response to COVID-19: Letter from Sir Simon Stevens and Amanda Pritchard. 17 Mar 2020. www.england.nhs.uk/coronavirus/publication/ next-steps-on-nhs-response-to-covid-19-letter-from-simon-stevens-and-amanda-pritchard/ 
$4 \quad$ Illman J, Discombe M. Majority of trust chiefs surveyed 'satisfied' with centre's covid-19 action. Health Service Journal 2020 Mar 24. www.hsj.co.uk/policy-and-regulation/majorityof-trust-chiefs-surveyed-satisfied-with-centres-covid-19-action/7027217.article

5 BBC News Online. Coronavirus: Thousands volunteer to help NHS with vulnerable. BBC News 2020 Mar 25. www.bbc.co.uk/news/uk-52029877
Published by the BMJ Publishing Group Limited. For permission to use (where not already granted under a licence) please go to http://group.bmj.com/group/rights-licensing/ permissions 